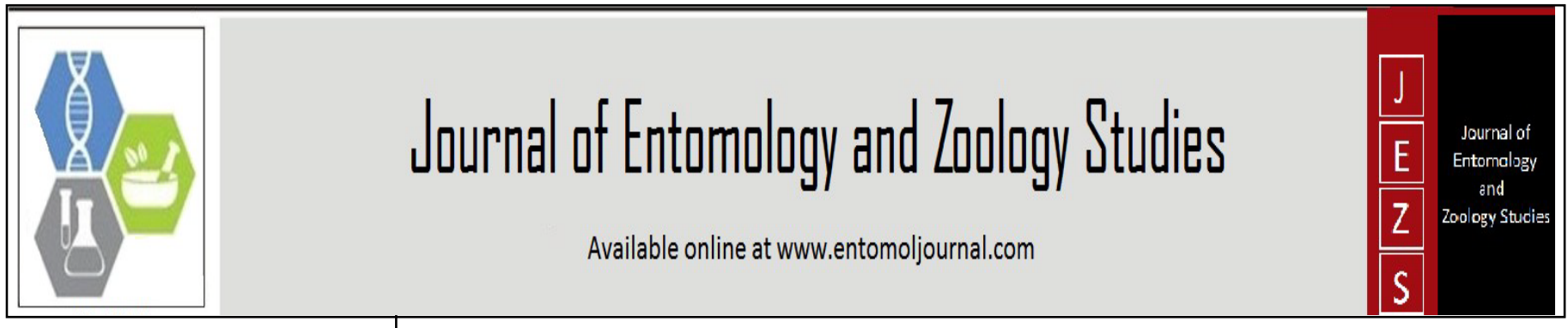

E-ISSN: 2320-7078

P-ISSN: 2349-6800

www.entomoljournal.com JEZS 2020; 8(6): 947-952 (C) $2020 \mathrm{JEZS}$

Received: 02-09-2020

Accepted: 12-10-2020

\section{BR Kharatmol}

Department of Fisheries

Resource Management, College

of Fishery Science, Maharashtra

Animal \& Fishery Sciences

University, Nagpur, Udgir,

Latur, Maharashtra, India

\section{Shenoy}

ICAR-Central Institute of Fisheries Education, Off Yari

Road, Versova, Mumbai, India

\section{AT Tandale}

Department of Fish Processing Technology, College of Fishery Science, Udgir, Latur,

Maharashtra, India

AT Markad

Department of Fisheries

Engineering, College of Fishery

Science, Udgir, Latur,

Maharashtra, India
Corresponding Author:

\section{R Kharatmo}

Department of Fisheries

Resource Management, College

of Fishery Science, Maharashtra

Animal \& Fishery Sciences

University, Nagpur, Udgir,

Latur, Maharashtra, India

\section{Fish catch rate and fishing efficiency of trawling off Raigad coast of Maharashtra, India}

\author{
BR Kharatmol, L Shenoy, AT Tandale and AT Markad
}

DOI: https://doi.org/10.22271/j.ento.2020.v8.i6m.7962

\section{Abstract}

The present study deals with the fish catch discard rate and fishing efficiency of commercial multi-day and single-day trawlers operated along the Raigad coast of Maharashtra. The trawlers from Raigad coast carried out fishing operations between $18^{0} 10^{\prime} 00^{\prime \prime} \mathrm{N}$ to $19^{\circ} 20^{\prime} 00^{\prime \prime} \mathrm{N}$ latitude and $72^{0} 45^{\prime} 00^{\prime \prime} \mathrm{E}$ to $73^{\circ}$ 30 ' $00^{\prime \prime}$ E longitude in the depth range between 12 to $52 \mathrm{~m}$. The study revealed that the average catch was $32.65 \mathrm{~kg} / \mathrm{h}$ and $32.09 \mathrm{~kg} / \mathrm{h}$ with an average discard of $7.63 \mathrm{~kg} / \mathrm{h}$ and $4.02 \mathrm{~kg} / \mathrm{h}$ for multi-day and singleday trawler respectively. The t-Test performed on fish catch and discards of multi-day and single-day trawlers did not reveal a statistically significant difference $(p>0.05)$ in a fish catch $(\mathrm{kg} / \mathrm{h})$ but in the case of multi-day trawlers, there was a statistically significant difference $(p<0.05)$ in fish discards $(\mathrm{kg} / \mathrm{h})$ between two fishing seasons i.e. 2016-17 and 2017-18 along the Raigad coast. The cod-end mesh size of the trawl net varied from 10 to $30 \mathrm{~mm}$ depending on the fishery resources harvested. Analysis of fish catch composition indicated the occurrence of 112 species of fishes in the catch of multi-day and singleday trawlers of the north Konkan region. In this paper changing trends in the catch, discards rates, and efficiency of trawlers are discussed.

Keywords: Catch, trawl net, fishing, Raigad

\section{Introduction}

Trawling has contributed to the increased marine fish production and has led to its widespread adoption by many countries. In India, trawlers have contributed a major part of the total marine fish production ${ }^{[21]}$. Maharashtra state has a total coastline of $720 \mathrm{~km}$ and a continental shelf area of 1,11,512 sq. km. The fishing fleet operating along the Maharashtra coast consisted of 13,016 mechanized boats, of which 5,613 were trawlers during 2016-17. The number of total marine fishing boats showed an increase of $3.4 \%$ over the previous year ${ }^{[1]}$. The fishing operations start from August after the monsoon ban period and continue up to May [11]. Marine fisheries around the world and India remain seriously threatened by fishing overcapacity, overfishing, and a range of environmental problems ${ }^{[14]}$. Trawl net fishing had significant direct and indirect effects on habitat, diversity, structure, and productivity of benthic communities ${ }^{[5]}$. Information on catch composition or fishing effort is even more limited, leading to data-poor situations ${ }^{[4,20]}$. Assessment of the catch composition, bycatch, and monthly variations in catch per unit effort (CPUE) of single-day trawlers along the Mumbai coast from October 2015 to May 2016 was carried out by ${ }^{[17]}$. Researchers must work with the best available data from different sources to provide sound advice for management decision-makers ${ }^{[2]}$. The study aimed to assess the efficiency of fish catch rate and their composition, fish discard and mesh size of cod-end, feet structure, and fishing operation information and to understand the changes in resource availability during the study period of commercial multi-day and single-day trawlers operated off Raigad coast.

\section{Material and Methods}

The study area of Raigad district is situated in the north Konkan region of Maharashtra and has a coastline of $240 \mathrm{~km}$ with a continental shelf area of $21000 \mathrm{~km}^{2}$ (Fig.1). Trawlers used for sampling in this area operated between $18^{0} 10^{\prime} 00^{\prime \prime} \mathrm{N}$ to $19^{0} 20^{\prime} 00^{\prime}$ N $\mathrm{N}$ latitude and $72^{\circ} 45^{\prime} 00^{\prime}$ E to $73^{\circ} 30^{\prime} 00^{\prime}$ E longitude. About 207 commercial trawlers operated along the Raigad coast of which 40 trawlers were registered at Alibaug. The study was undertaken for two consecutive fishing seasons from September 2016 to May 2017 and September 2017 to May 2018. Four multi-day and single-day commercial trawlers were selected for data collection as per statistical design ${ }^{[19]}$. 
Data on catch and discards of fishes and shellfishes of trawlers were collected fortnightly on regular basis.

Details of fishing operations and vessel information were obtained from the two different sources from boat owners and crew of the trawlers who were directly involved in fishing and partly from vessel registration certificates. Information was obtained by conducting interviews of randomly selected fishers when they arrived at the landing center for unloading the catch. The method was applied following ${ }^{[12]}$.

Different sampling approaches were considered for collecting detailed information on the characteristics of the fishing fleets and fishing activity- fishing fleet: several vessels; data on overall length (OAL), gross tonnage (GT), engine power (HP), gear in use, license, fishing area, etc. were collected for each boat to update this information for the period covered by the study. Onboard information collected comprised of date, depth of shooting \& hauling of the trawl net, geo-location of the fishing operation, time of shooting \& hauling of the net, type of net, mesh size (Cod end), total catch per boat per trip, and haul, total discards (kgs), number of hauls per day per haul. Species composition and size of catch obtained through a sampling of trawlers during unloading on the fishing harbor. Along with fishing information, an unsorted portion of the discarded catch was collected as a sample representing the haul. The catch was identified up to species level using ${ }^{[8,9]}$. Data were analyzed using Microsoft Excel, 2013. A t-Test (Paired Two Sample for Means) was used to determine whether data is statistically significant or not.

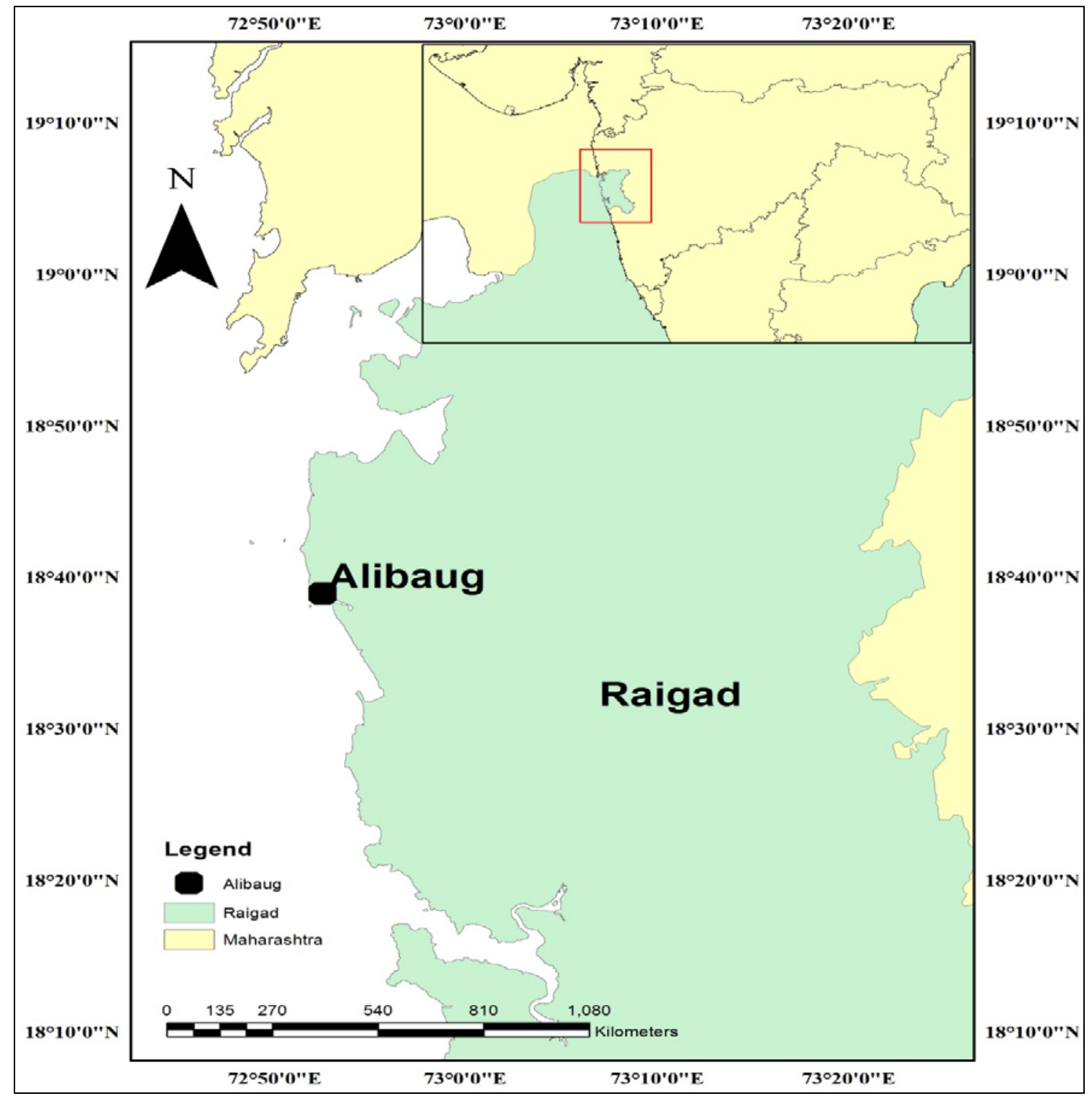

Fig 1: Map showing study area of Alibaug (Raigad) landing center

\section{Results and Discussion}

\section{Fisheries characterization}

It was observed that about 207 number of commercial multiday and single-day trawlers were operated along the Raigad coast. Overall length of trawlers varied from 13.50 to $18.10 \mathrm{~m}$ and 11.80 to $15.40 \mathrm{~m}$ in the case of multi-day and single-day trawlers respectively. Most of the trawlers were fitted with 90 to $195 \mathrm{hp}$ engines according to their size and carrying capacity. All vessels had registered with regulatory authority and obtained a fishing license. Multi-day and single-day trawlers carried 4-6 different types of trawl nets and cod-end mesh size varied from $10-30 \mathrm{~mm}$ depending on the target of the demersal fishery resources.

\section{Fishing operations}

In Raigad coastal district, fishing operations carried out by trawlers between $18^{0} 10^{\prime} 00^{\prime \prime} \mathrm{N}$ to $19^{0} 20^{\prime} 00^{\prime \prime} \mathrm{N}$ latitude and $72^{0} 45^{\prime} 00$ ” $\mathrm{E}$ to $73^{0} 30^{\prime} 00^{\prime}$ ' $\mathrm{E}$ longitude, the duration of 
fishing trips by multi-day trawlers varied from 2 to 5 days. The depth of fishing operation ranged from 12 to $52 \mathrm{~m}$ and 12 to $26 \mathrm{~m}$ in the case of multi-day and single-day trawlers respectively. The trawling operations were carried out during the daytime between 6.00 am to $6.00 \mathrm{pm}$. Generally, trawlers maintained cruising speed at $1250 \mathrm{rpm}$ and trawling operation at $1100 \mathrm{rpm}$. On an average, trawlers undertook 3 hauls per day, each haul of 3 hours duration.

\section{Catch and Discards}

The present study investigated that the beginning and the end of the fishing season; was characterized by low fishing intensity and varied from year to year depending on the recruitment of the commercial species. After the fishing closure (June- July), trawl activities were low in the month of August and September, as weather conditions were not suitable and trawling operations were concentrated near the coast (beyond $10 \mathrm{~m}$ but within $20 \mathrm{~m}$ depth). High exploitation rate was detected from October to March with a peak in
September and October months during the fishing season. Fishing intensity decreased from April to May when the low availability of demersal resources made it economically unprofitable to fish in the area.

The present study revealed that the average catch rate of the multi-day and single-day trawler was $33.66 \mathrm{~kg} / \mathrm{h}$ and 33.19 $\mathrm{kg} / \mathrm{h}$ respectively during 2016-17. The maximum catch rate of $44.17 \mathrm{~kg} / \mathrm{h}$ for multi-day and $42.50 \mathrm{~kg} / \mathrm{h}$ for single-day trawlers was reported in November. However, discards by multi-day trawlers ranged from 6.67 to $10.67 \mathrm{~kg} / \mathrm{h}$ and by single-day trawlers 3.00 to $6.00 \mathrm{~kg} / \mathrm{h}$. Discards were relatively less in single-day trawlers is given in Fig.2 and Fig.3. During the second year study period 2017-18, the average catch rate of the multi-day and single-day trawler was $31.64 \mathrm{~kg} / \mathrm{h}$ and $30.19 \mathrm{~kg} / \mathrm{h}$ with average discards of $6.22 \mathrm{~kg} / \mathrm{h}$ and $3.89 \mathrm{~kg} / \mathrm{h}$, respectively. Peak fishing activities were observed during November followed by January to February in terms of landing is given in Fig.4 and Fig.5.

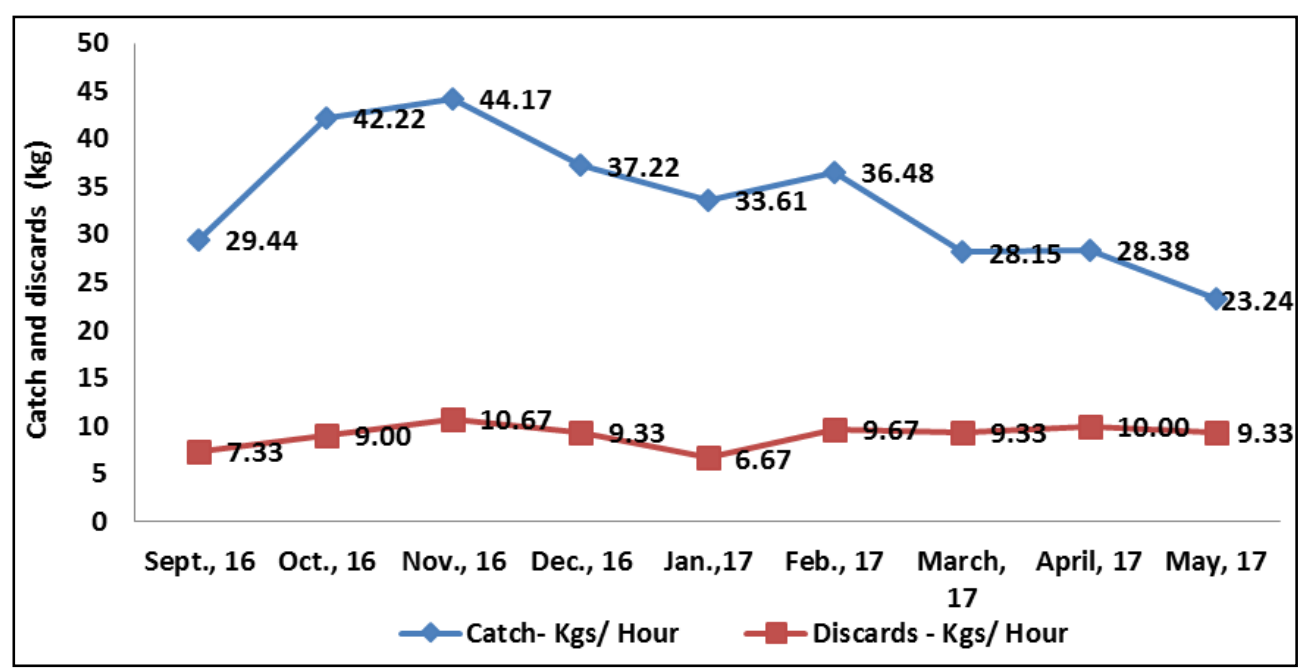

Fig 2: Monthly variation in catch and discards from multi-day trawlers at Alibaug (Raigad) during 2016-17

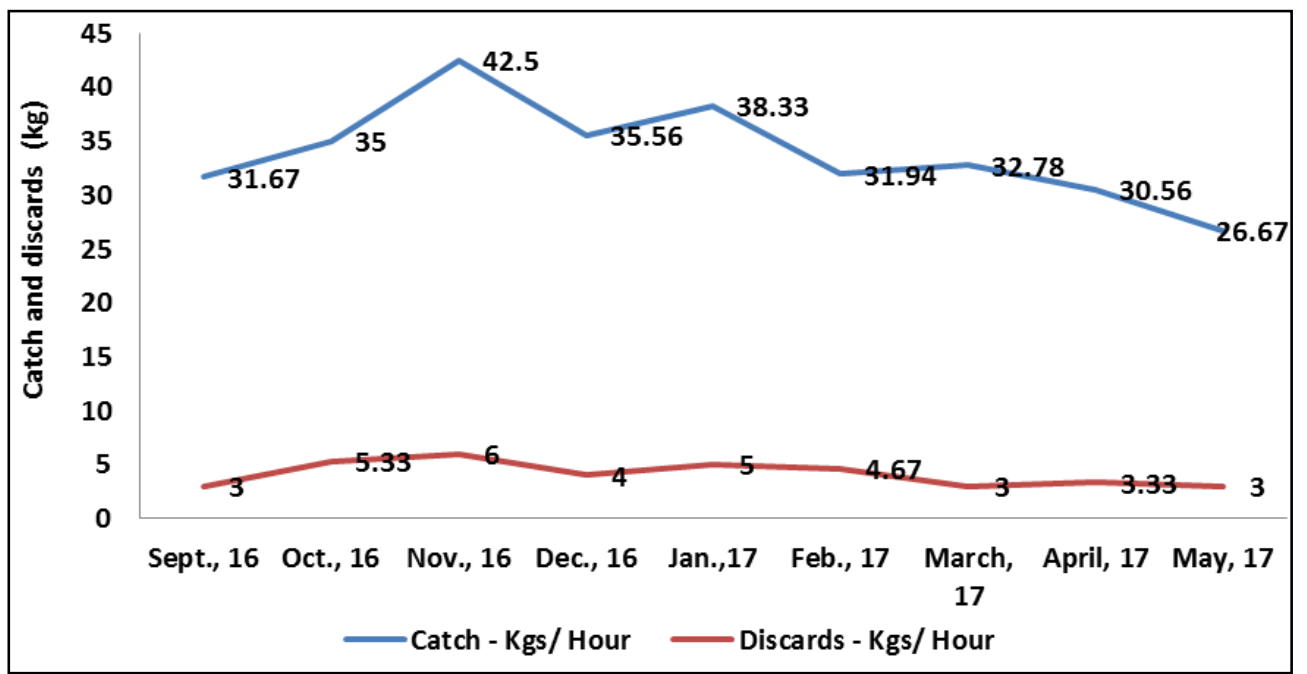

Fig 3: Monthly variation in catch and discards from single-day trawlers at Alibaug (Raigad) during 2016-17 


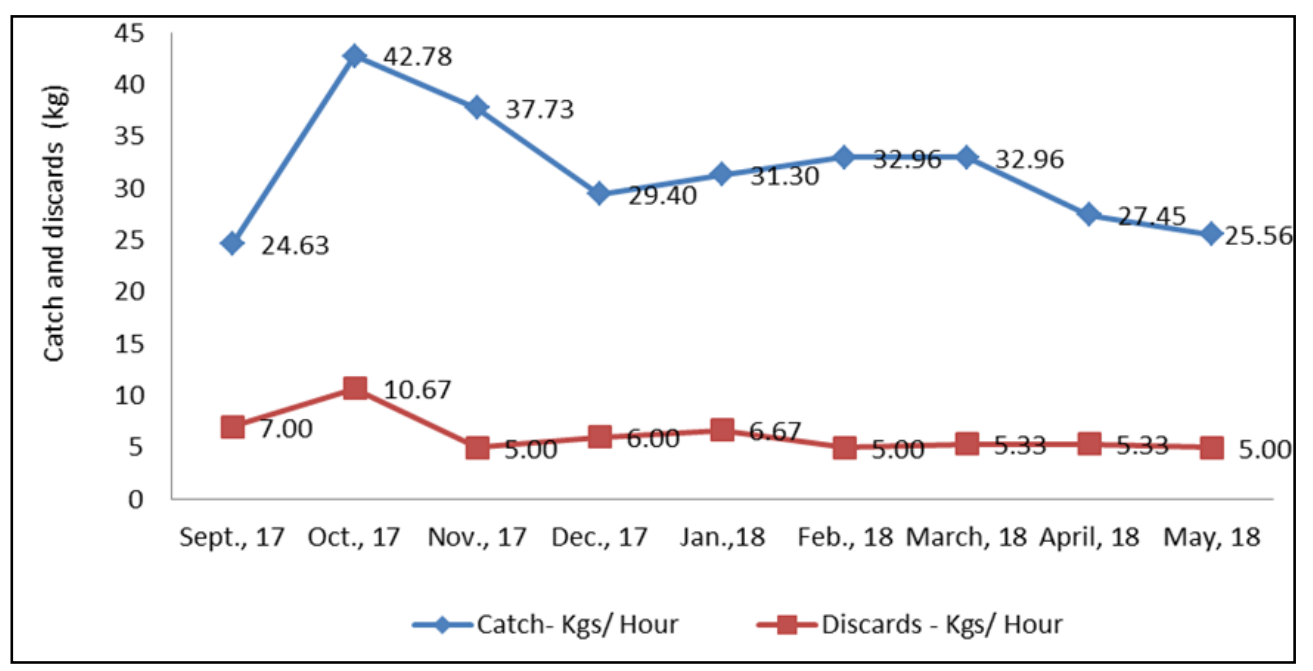

Fig 4: Monthly variation in catch and discards from multi-day trawlers at Alibaug (Raigad) during 2017-18

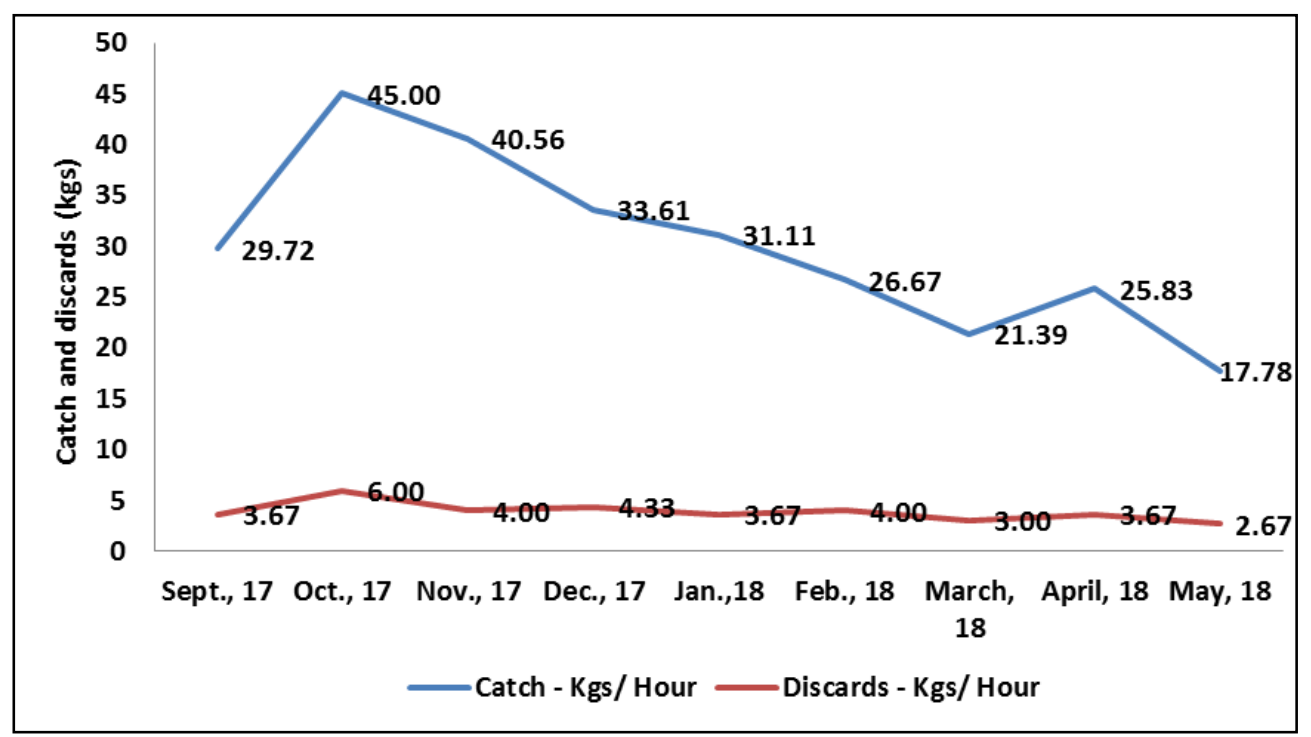

Fig 5: Monthly variation in catch and discards from single-day trawlers at Alibaug (Raigad) during 2017-18

Considering the data for two years, the study revealed that the average catch was $32.65 \mathrm{~kg} / \mathrm{h}$ and $32.09 \mathrm{~kg} / \mathrm{h}$ with average discards of $7.63 \mathrm{~kg} / \mathrm{h}$ and $4.02 \mathrm{~kg} / \mathrm{h}$ for multi-day and singleday trawler respectively.

The t-Test performed on fish catch and discards of multi-day and single-day trawlers did not reveal a statistically significant difference $(p>0.05)$ in a fish catch $(\mathrm{kg} / \mathrm{h})$ but in the case of multi-day trawlers, there was a statistically significant difference $(p<0.05)$ in fish discards $(\mathrm{kg} / \mathrm{h})$ between two fishing seasons i.e. 2016-17 and 2017-18 along the Raigad coast.

Catch composition, bycatch characterization, and monthly variations in catch per unit effort (CPUE) generated by single day trawlers along Mumbai coast that the maximum catch was contributed by Sciaenids (35\%), followed by Sharks and Rays (10\%), Anchovies (10\%), Prawns (8\%), Bombay duck (6\%) and other demersal species. Mean monthly bycatch generated by shrimp trawling ranged from 11.82 to $20.65 \mathrm{~kg}$ $\mathrm{h}-1$, in different months with an overall average of $16.82 \mathrm{~kg}$ $\mathrm{h}-1$ [17]

Catch per hour was maximum during October for multi-day trawlers $(73.27 \mathrm{~kg})$ and during December for single-day trawlers $(22.70 \mathrm{~kg})$ with maximum discards per hour by multi-day trawlers i.e. $15.6 \mathrm{~kg}$ was during September, while it was October for single-day trawler $(4.03 \mathrm{~kg}$ ) from Mumbai coast ${ }^{[3]}$. An average catch rate of $49.90 \mathrm{~kg} /$ hour and $28.20 \mathrm{~kg} /$ hour with fish discards at an average of $7.7 \mathrm{~kg} /$ hour and 3.84 $\mathrm{kg} /$ hour by commercially operated multi-day and single-day trawlers respectively from Ratnagiri coast ${ }^{[12]}$. Studies showed variation in the catch composition and discard percentage compared to the present study along the coast of Mumbai ${ }^{[15]}$. Earlier studies recorded about 101 species from the marine capture fisheries bycatch and discard at Karanja and Mora landing centers from Uran (Raigad), Navi Mumbai, Maharashtra during October- November 2009. The catch recorded juveniles and sub-adults of commercially valuable organisms. Juvenile discards from trawling operations, off Vishakhapatnam, were 25 to $30 \%{ }^{[10]}$.

Catch per hour by otter trawling in the Arabian Sea was 198 $\mathrm{kg} /$ hour ${ }^{[16]}$. The catch rate of trawlers fluctuated from 30 to $50 \mathrm{~kg}$ per hour during 1990-2007. From 2008 onwards, the catch rate increased and reached about 75kg per hour in 2012. Attributed the increase in catch rates due to the introduction of high-speed engines since $2010^{[6]}$.

\section{Catch Composition}

Major catch composition of multi-day and single-day trawlers included non-penaeid prawns, Rastrelliger kanagurta, Lepturacanthus savala, Otolithus cuvieri, Harpodon nehereus, Coilia dussummieri, Arius maculatus, Penaeid 
prawns, Lactarius lactarius, and Scomberomorus guttatus. Species like Otolithus cuvieri contributed the maximum to landings of the multi-day trawler. In the case of single-day trawlers, non-penaeid prawns contributed maximum followed by Lepturacanthus savala and Rastrelliger kanagurta in terms of mean landing during the study period along the Raigad coast.
The findings of the present study revealed the abundance of non-penaeid prawns, Rastrelliger kanagurta, and Lepturacanthus savala in terms of catch percentage in both single-day and multiday trawlers. Major fish catch percentage during the study period of Raigad coast by multi-day and single-day trawlers is given in Fig.6 and Fig.7.

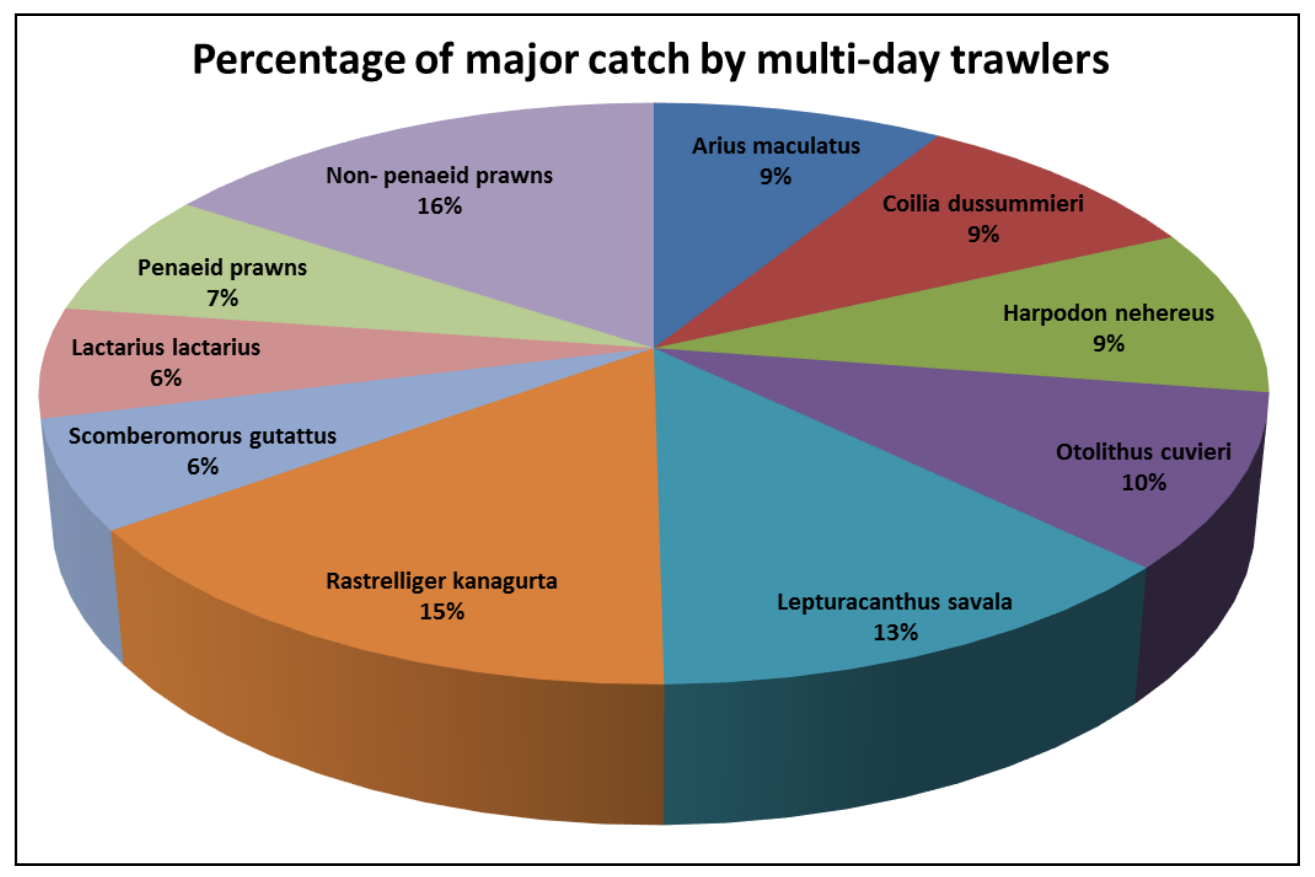

Fig 6: Percentage of major catch by multi-day trawler

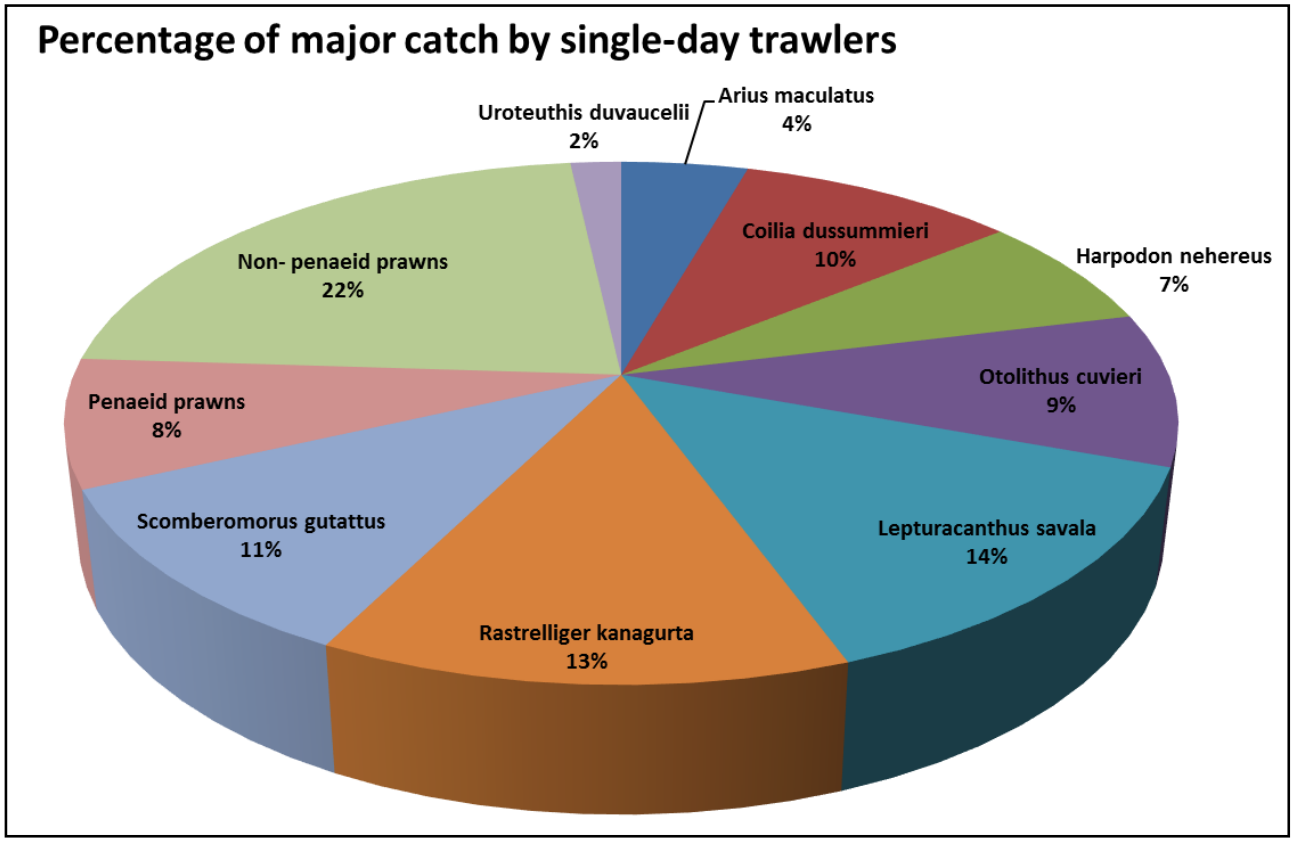

Fig 7: Percentage of the major catch by single-day trawler

In the present study, 112 species of fishes were reported from the catch of commercial operated multi-day and single-day trawlers. Dominant species belonged to the Order Perciformes. Based on a study conducted by [3] that participatory geographic information system in trawl fisheries for preparation of thematic maps of marine fisheries resources along the Mumbai coast, Maharashtra during 2013-14, around 121 species landed by commercial trawlers were reported. Considering findings of the present study that recorded one hundred twelve species landed by multi-day and single-day trawlers of Mumbai during 2016-17, there is a clear indication that there is a decrease in the number of species recorded compared to the previous year.

The exploitation of groups like the Seer fishes, Mackerels, Pomfrets, Crabs, Prawns, and Lobster has reached the near optimum level. Increasing fisher population and fishing efforts and the level of dependency on marine fishery resources are the major causes of overexploitation ${ }^{[13]}$. The 
underexploited stock includes anchovies, other clupeids, billfishes, perches, mackerels, elasmobranches, carangids, and sciaenids [18]. To avoid overexploitation and to ensure sound growth, the state has to adopt a rationalized approach to determining the number and size of fishing vessels, the type of fishing gears, and operational equipment for reducing the fishing efforts from a specific area to ensure sustainable marine living resources for posterity. FAO Code of conduct responsible fisheries (1995) ${ }^{[7]}$, states some principles and international standards of behavior for responsible practices with the view to ensure the effective conservation, management, and development of marine living resources, with due respect for the ecosystem and biodiversity. Database which was created in the present study on fishing fleet, fishing operation, fish catch (kg) per hour, fish discards (kg) per hour, etc. would assist policymakers in preparing conservation and resource management policies

\section{Conclusion}

Analysis of fish catch composition in the present study indicated the occurrence of 112 species of fishes in the catch of multi-day and single-day trawlers. Dominant species belonged to the Order Perciformes. An average catch was reported $33.66 \mathrm{~kg} / \mathrm{h}$ and $33.19 \mathrm{~kg} / \mathrm{h}$ and discards of $9.04 \mathrm{~kg} / \mathrm{h}$ and $4.15 \mathrm{~kg} / \mathrm{h}$ for multi-day and single-day trawlers respectively. Depth of trawl net fishing operation by multiday trawlers was varied from 12 to $52 \mathrm{~m}$ along the Raigad coast of Maharashtra. Diversification of fishing efforts in the deep sea requires serious consideration to reduce overcrowding in inshore waters, reducing fishing pressure on fish stocks, and minimizing juvenile catch and discards. The database created on fishing fleet, fishing operation, fish catch and discards (kg) per hour, etc. would assist policymakers in preparing conservation and resource management policies.

\section{Acknowledgments}

The authors are grateful to the Director and Vice-chancellor ICAR- Central Institute of Fisheries Education, Deemed University, Versova, Mumbai for providing necessary facilities for carrying out this research work.

\section{References}

1. Anon, Fish Production Report 2016-17. Department of Fisheries, Government of Maharashtra, Mumbai, 2017, 137.

2. Berkes F, Mahon R, McConney P, Pollnac R, Pomeroy R. Managing Small-Scale Fisheries. Alternative Directions and Methods. Ottawa, Canada: International Development Research Centre, 2001, 320.

3. Bhendekar SN, Shenoy L, Raje SG, Chellappan A, Singh R. Participatory GIS in trawl fisheries along Mumbai coast, Maharashtra. Indian Journal of Geo-marine Sciences 2016;45(8):937-942

4. Chuenpagdee R, Liguori L, Palomares ML, Pauly D. Bottom-up, global estimates of small-scale fisheries catches. Fisheries Center Research Report 2006;14:110.

5. Collie JS, Escanero GA,Valentine PC. Effects of bottom fishing on the benthic megafauna of Georges Bank. Mar. Ecol. Prog. Ser 1997;155:159-172.

6. Dineshbabu AP. The trawl fishery of the eastern Arabian Sea, paper presented at the APFIC Regional Expert Workshop on Tropical Trawl Fishery Management, Thailand, 2013.

7. FAO. Code of Conduct for Responsible Fisheries, 1995;
41.

8. Fisher W, Bianchi G. FAO species identification sheet for fishery purpose. Western Indian Ocean (Fishing Area 51). Rome, Food and Agricultural Organization of the United Nations 1984;(1):6.

9. Froese R, Pauly D. Fish Base. World Wide Web electronic publication 2011. http://www.fishbase.org

10. Gordon A. The bycatch from Indian shrimp trawlers in the Bay of Bengal. Bay of Bengal Programme, BOBP/WP/68, 1991, 29.

11. Government of India, Order no.30035/15/97-Fy(T-1) Vol. III. Department of Animal Husbandry, Dairying, and Fisheries, Ministry of Agriculture, Government of India. Krishi Bhavan, New Delhi, 2014.

12. Jasprit S, Singh R, Mohite AS, Bhendekar SN, Shenoy L. Journal of Environmental Bio-sciences 2017;31(1):27-31.

13. Kanaga V. Fishermen livelihoods and marine fishery resources: An impact study in Gulf of Mannar coast, Tamil Nadu. Journal of Entomology and Zoology Studies 2017;5(6):149-152.

14. Meaden G, Jand Aguilar-Manjarrez J. Advances in geographic information systems and remote sensing for fisheries and aquaculture, FAO Fisheries and Aquaculture Technical Paper No.552. Rome, Italy. 2013

15. Pawar Prabhakar R. Assessment of bycatch and discards in marine capture fisheries from Uran (Raigad), Navi Mumbai, Maharashtra. The Ecoscan 2011;5(3-4):105109.

16. Rao KV. Exploratory Fishing, $20^{\text {th }}$ Anniversary Souvenir, Central Marine Fisheries Research Institute, Kochi, India, 1967.

17. Samanta R, Chakraborty SK, Shenoy L, Nagesh TS, Behera S, Bhoumik TS. Bycatch characterization and relationship between trawl catch and lunar cycle in single day Shrimp Trawls from Mumbai Coast of India. Regional Studies in Marine Science 2018;17:4758.

18. Sathiadhas R, Kumar N, Raghu R. Marine Fisheries management for Sustainable development, technology transfer Series-2, CMFRI, Cochin, 1995, 26.

19. Snedecor G, Wand Cochran WG. Statistical methods, Edn.6, Oxford and IBH Publishing Co., New Delhi, 1967, 593.

20. Salas S, Chuenpagdee R, Seijo JC, Charles A. Challenges in the assessment and management of small-scale fisheries in Latin America and the Caribbean. Fisheries Research 2007;87:5-16.

21. Srinath M. An appraisal of the exploited marine fishery resources of India. In: Status of exploited marine fishery resources of India, edited by $\mathrm{M}$. Mohan Joseph and A.A.Jayaprakash, (Central Marine Fisheries Research Institute, Kochi, India), 2013, 1-17. 